\title{
Exploring the feasibility of private micro flood insurance provision in Bangladesh
}

\author{
Sonia Akter, Roy Brouwer, Pieter J.H. van Beukering, Laura French, \\ Efrath Silver, Saria Choudhury and Syeda Salina Aziz'
}

This paper aims to contribute to the debate on the feasibility of the provision of micro flood insurance as an effective tool for spreading disaster risks in developing countries and examines the role of the institutional-organisational framework in assisting the design and implementation of such a micro flood insurance market. In Bangladesh, a private insurance market for property damage and livelihood risk due to natural disasters does not exist. Private insurance companies are reluctant to embark on an evidently unprofitable venture. Testing two different institutionalorganisational models, this research reveals that the administration costs of micro-insurance play an important part in determining the long-term viability of micro flood insurance schemes. A government-facilitated process to overcome the differences observed in this study between the nonprofit micro-credit providers and profit-oriented private insurance companies is needed, building on the particular competence each party brings to the development of a viable micro flood insurance market through a public-private partnership.

Keywords: Bangladesh, flood insurance, institutional design, natural disasters, viability

\section{Introduction}

Insurance has been referred to as an effective tool for reducing, sharing and spreading climate change-induced disaster risks in both developed and developing countries (Bouwer and Vellinga, 2002; Hoff et al., 2003; Mills, 2004; Botzen and van den Bergh, 2008; Brouwer and Akter, 20I0). The institutional structure of insurance has come to occupy centre stage in the debate about financing disaster risks with proponents of public and private financial risk management systems on either side.

Dworkin (2000) emphasises the important role of state management of risks through the provision of insurance, offering a model of egalitarian justice within the social welfare realm of the economy. In contrast, Shiller (2003) argues for private income insurance in an economy without government intervention. He envisions the emergence of a private insurance market, which would offer livelihood insurance, home equity insurance and income-linked loans to share the society-wide risks. The primary driving force behind Shiller's (2003) thesis is the potential financial gain from increased risk sharing within the society that could accrue to private insurance companies and financial institutions.

Both theories of a public and private risk management system have been criticised by political philosophers and financial economists. Farrelly (2007) claims that Dworkin's 
(2000) theory of a 'hypothetical insurance market' is an ineffective theory of social justice because it is unable to address practical trade-offs that arise in non-ideal societies facing resource scarcity. Shiller's (2003) concept of livelihood risk sharing has been rejected on the grounds of lack of commercial viability and effective demand. Dowd (2003) argues that the implementation of livelihood insurance or incomelinked loans is constrained by a wide variety of different institutional risks associated with private supply provision, including credit or default risks and legal risks. Similarly, Rose (2004) rejects the concept of livelihood insurance or home equity insurance, referring to the fact that existing markets do not provide such risk-sharing contracts for a reason: markets for such contracts are incomplete, impractical and unfeasible.

Against this background, this paper aims to contribute to the international academic discussion on appropriate institutional-economic structures of risk management. It assesses the financial viability and institutional preconditions that need to be in place for successful provision of a micro-insurance scheme. Shiller's (2003) proposal to create a private insurance market serves as a model to test the financial viability of a flood insurance scheme in Bangladesh where a large proportion of the population confronts livelihood and house property damage risks due to catastrophic events. A mixed quantitative-qualitative research approach was followed. In a large-scale rural household survey carried out between August and October 2006, 2,400 floodplain residents were asked about their demand for different forms of insurance schemes: crop damage, house property and unemployment insurance schemes. Households' willingness to pay (WTP) was estimated and compared with expected indemnity payouts by insurance providers, within the framework of two different organisational models of micro-insurance supply: a 'partner-agent' model (PA) and a 'fullservice' (FS) model-which are explained in the following sections. The qualitative assessment is based on semi-structured interviews and a workshop with decisionmakers in private insurance companies, micro-finance institutions (MFIs) and nongovernmental organisations (NGOs) to investigate the viability of private insurance provision in Bangladesh.

The remainder of this paper is organised as follows: the second section presents a discussion of catastrophe risk insurance in a developing country context. The case study is presented in the third section, followed by floodplain residents' characteristics and attitudes towards buying micro flood insurance and their willingness to pay insurance premiums in the fourth and fifth sections, respectively. The commercial viability of micro flood insurance schemes is addressed in the sixth section. The results of the in-depth interviews and the workshop are presented in the seventh section. Finally, the eighth section contains some conclusions and policy recommendations.

\section{Insurance against catastrophe risk in a developing country context}

With regard to long-term sustainability of micro-insurance in effectively transferring and hedging natural disaster risk, the existing literature considers four key 
criteria: contribution to risk reduction; commercial viability; affordability; and governance (ProVention Consortium/IIASA, 2005). Commercial viability and affordability often are considered the most challenging criteria to be fulfilled in developing economies given the nature of the environmental and financial risks to the insurer and the financial constraints on the insured.

Natural disasters result in systematic losses correlated across clients and geographical regions. Therefore, insurers face the risk of having to compensate large losses due to a disaster event that affects clients in an entire community or region. As a result, the standard principle of paying damage compensation to affected clients only by pooling resources from non-affected clients typically does not apply (Duncan and Myers, 2000). Furthermore, the scope of reinsuring disaster insurance schemes is limited or the costs of reinsurance are very high (ProVention Consortium/IIASA, 2005). Due to these obstacles, private insurers have been reluctant to offer policies that cover flood and other natural hazards.

From the perspective of the insured, insurance demand in low-income economies frequently is low due to limited financial resources and thus has been found insufficient to ensure risk pooling even within the community or region. Households exposed to the risk of natural catastrophes in developing countries usually are part of the poorer segments of society (IPCC, 2007). Previous work in one of the most flood-prone areas of Bangladesh shows that poor households are more exposed to the risk of flooding than wealthier households, which are able to cope better with preventing damage costs (Brouwer et al., 2007). This study also revealed that poorer households suffer relatively higher damage costs because of flooding. Another study conducted in the same floodplain area revealed that 60 per cent of its residents are willing but unable to contribute financially to the construction of a protective embankment in the region because of insufficient financial means (Brouwer et al., 2009). These findings imply that, even if an insurance provider exists, poor households in Bangladesh probably cannot afford commercial insurance due to income constraints.

Nevertheless, disaster risk insurance programmes have been introduced in many developing countries (Mechler, Linnerooth-Bayer and Peppiatt, 2006). Although experiences and available information are too limited to draw general conclusions about such schemes, disaster risk insurance has not been very successful overall from a commercial standpoint. Nearly 30 years ago a multi-peril crop insurance programme was introduced by the Government of Bangladesh, covering the crop damage risks of more than I5,000 farmers (Miah, I992). The initiative was commercially unsuccessful as claims consistently exceeded premium revenues. In Io of its I7 years of operation, the loss ratio was more than 400 per cent (Rahman, 2007). The governmentoperated National Agriculture Insurance Scheme (NAIS) in India also operates at a substantial loss. During its five years of operation, premium revenues have covered only one-third of indemnity claims (Raju and Chand, 2008). Taking into account the administration costs, the premiums only covered I2 per cent of programme costs in the southern Indian state of Karnataka (Kalavakonda and Mahul, 2005).

In some instances, providers offer micro-insurance products together with other financial services. For example, micro-credit providers offer insurance products jointly 
with micro-credit loans or savings schemes. Proshika, one of the largest microcredit providers in Bangladesh, has offered compulsory group-based insurance since I997. Under this programme, clients are required to deposit two per cent of their savings in an insurance fund. In the event of any loss incurred by the clients due to natural disasters, twice the amount of the accumulated savings in the insurance fund is returned to them. Bundled disaster insurance schemes have three key advantages. First, the system enables the insurer to diversify risks by adding other risks to the portfolio that are uncorrelated across clients. Second, adverse selection is reduced if clients are obliged to purchase the insurance, including those facing low flood risk. Third, if the insurance is offered jointly with other products, transaction costs are lower than if they were sold separately.

Despite these advantages from the provider's viewpoint, there is a real risk that bundled insurance affects the affordability of micro-insurance provision as it adds to the clients' purchasing costs. Compulsory insurance schemes that are bundled with micro-credit or savings schemes may become a barrier to low-income households to access credit facilities as such schemes increase the costs of borrowing or reduce the returns from savings. Therefore, insurance holders usually are averse to compulsory insurance programmes, as is evidenced for example in the case of the Self-Employed Women's Association (SEWA) in India discussed in a review of existing microinsurance programmes in developing countries (Mechler et al., 2006). The SEWA initially offered a mandatory life insurance policy together with micro-credit, but the scheme was changed to voluntary provision after complaints from clients.

\section{Case study}

In the context of both low demand and supply of natural disaster insurance schemes, a model was constructed to test the commercial viability of such an insurance scheme in Bangladesh. Weather-related risk is a major cause of rural income fluctuations in Bangladesh. Impact assessments carried out by the Intergovernmental Panel on Climate Change (IPCC) identify Bangladesh as one of the world's worst victim countries in terms of the negative impacts of climate change. Those expected to be hardest hit by natural disasters are the poorer segments of society, which lack adequate means to take protective action and have little capacity to cope with the loss of property and income (IPCC, 2007).

Traditionally, the management of flood disaster risks in Bangladesh has focused on infrastructural engineering measures, such as embankments, and ex-post flood relief measures, such as post-disaster credit facilities. In recent years, the concept of 'proactive adaptation' has attracted more attention among poverty alleviation programmes in Bangladesh to deal with natural disaster risks. While the use of micro-insurance to cover life and health risks is prevalent to some extent, its use to hedge against natural disaster losses in rural areas is still in its infancy. The National Adaptation Programme of Action, prepared by the Ministry of Environment and Forests (2005) of Bangladesh, suggests exploring options for spreading natural disaster risks by investigating the potential of a flood insurance market. 
To explore the demand for flood insurance, a household survey was conducted. Five districts located along the three major rivers in Bangladesh (Jamuna, Meghna and Padma) were selected on the basis of damage intensity levels observed during the

Figure 1 Geographical location of the case study area

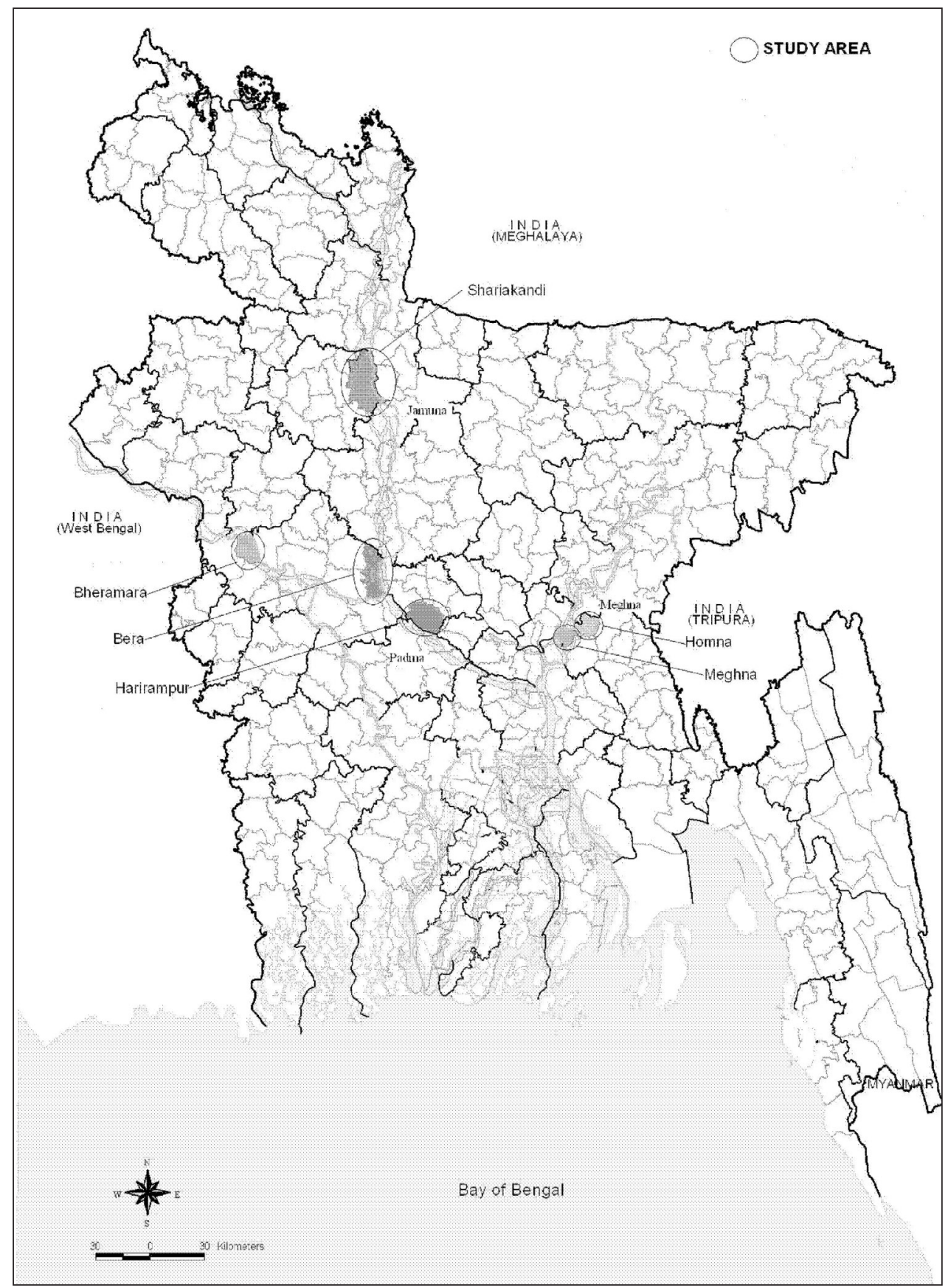

Source: Geographic Information System cell, Department of Local Government Engineering, Dhaka, Bangladesh. 
2004 disaster flood (Figure I). The selection of households in each of the villages followed a systematic random sampling method. The questionnaire was based on focus-group discussions and pre-tests with approximately 40 individual household heads in different parts of the study area. In total, 2,400 household heads were interviewed during the main survey from the third week of August until the first week of October 2006 by I5 trained and experienced interviewers. The survey questionnaire consisted of about 50 questions and was divided into three sections: I) sociodemographic household characteristics (gender, age, occupation, education, family size, sources of income, assets, and standard of living); 2) the type and extent of suffering due to annual and incidental disaster flooding (flood frequency, flood duration, inundation level, type and extent of flood damage and level of preparedness); and 3 ) attitudes to and willingness to pay for micro flood insurance. In this third and final part of the questionnaire, respondents were presented with a hypothetical insurance programme.

A series of focus-group discussions was conducted to determine the features of the hypothetical insurance product. During the sessions, the authors recognised respondents' vast unfamiliarity with a standard insurance contract. Participants struggled to comprehend any complex issues associated with insurance schemes, including partial insurance coverage and bundled insurance contracts. As a result, offering a standalone insurance scheme, involving full coverage of the damage bill, appeared to be the only plausible way forward. During the household survey, the hypothetical 'flood insurance product' was offered to the respondents in the following form:

I would now like to ask you a number of questions related to the potential of introducing a flood insurance scheme in this area. The principle of the proposed insurance scheme is as follows: you pay a fixed amount of money for the next five years - an insurance premiumevery week, two weeks or month depending on your preferred payment frequency. Only in the case of an officially acknowledged disaster flood, like the one in 2004, will you receive compensation for any losses suffered. If there is a disaster flood and you claim compensation, an independent survey or will visit you and assess the extent of the damage you suffered. Based on the surveyor's independent assessment you will be compensated. The terms and conditions of your insurance scheme are protected by law.

After a detailed description of the insurance scheme, respondents were asked three questions. First, whether or not they would be willing to participate in principle in an insurance scheme to reduce the risk of various forms of flood damage. Respondents who replied positively to the first question then were asked how frequently they would want to pay for their most preferred insurance scheme and who they would prefer to have as a provider. Hence, they were able to choose their preferred payment frequency, insurance provider and insurance product(s). Subsequently, a total of six different starting bids representing insurance premiums, ranging between USD 0.07 (Taka 5) and USD 0.7I (Taka 50), were used for the third valuation question. The bid levels were assigned randomly across respondents to avoid starting-point bias 
(Mitchell and Carson, I989). The weekly premiums were based on a previous largescale survey to test household's willingness to pay for a flood protection embankment in one of the study areas and thorough pre-testing in the pre-tests.

\section{Respondent characteristics and attitudes to micro flood insurance}

Table I compares the general demographic and socioeconomic characteristics of the sample with the national population statistics. The average age of the respondents was 44 years, whereas the national average was slightly lower (42 years). Approximately one-half (50.7 per cent) of the respondents were unable to read and write. Slightly more than one-quarter (26.8 per cent) finished primary school and only I4.o per cent finished high school. Around one-third (35.0 per cent) of the sample households were involved full-time in agricultural activities to support their livelihood. In addition, I6.4 per cent of the sample population consisted of agricultural day labourers. Trade (I5.0 per cent), transport (ferry/taxi worker) (5.5 per cent), service (administrator) (6.5 per cent), construction (3.2 per cent) and fishery (2.I per cent) were other sources of livelihood in the study areas. Average annual household income (related to the past I2 months) was around USD I,29I, while one-half of the sample population earned USD 846 per year. Dividing the median annual income by average household size and I2 months reveals that per capita income equals USD I4 per month, which is exactly the same as the national average rural per capita income (Bangladesh Bureau of Statistics, 2005).

Approximately one-half of the sample households interviewed in this study agreed in principle to participate in the proposed disaster insurance programme $(n=I, I 60)$. The two main reasons why respondents refused to participate in the insurance scheme were 'limited financial income' (45 per cent) and 'dislike of the terms and conditions of the proposed flood insurance scheme' (32 per cent). Around seven per cent $(n=8 \mathrm{I})$ of the respondents said that they were unable to assess the usefulness of the proposed hypothetical insurance scheme while another five per cent did not believe that they would be compensated by the insurer.

Less than two per cent of the sample respondents had ever bought an insurance policy and more than two-thirds were unfamiliar with how an insurance contract works. This finding is consistent with existing empirical evidence presented in other studies (Gine, Townsend and Vickery, 2008; Mechler et al., 2006), which document cases where insurance clients in developing countries were found to be widely ignorant of the technical aspects of an insurance contract. The current study furthermore detects a significant positive relationship (Chi square $=23.28, \mathrm{p}<0.00 \mathrm{I}$ ) between respondents' level of insurance familiarity and their decision to participate in the insurance scheme (see Table 2). Respondents who were more familiar with how an insurance scheme helps in pooling risk among communities were more willing to participate than those who were less familiar. There is a significant positive correlation 
Table 1 Summary statistics of respondent (household) demographic and socioeconomic characteristics

\begin{tabular}{|c|c|c|c|}
\hline Respondent (household) characteristic & & Sample & $\begin{array}{l}\text { National average } \\
\text { (for rural areas) }\end{array}$ \\
\hline Male-headed household (\%) & & 99 & 90 \\
\hline Respondent average age (median value) & & $44(42)$ & 42 \\
\hline \multirow[t]{3}{*}{ Literacy rate respondent (\%) } & Illiterate & 50.7 & 61.0 \\
\hline & Primary school & 26.8 & \\
\hline & High school & 14.0 & \\
\hline \multicolumn{4}{|l|}{ Respondent occupation (\%) } \\
\hline \multirow[t]{4}{*}{ Agriculture, forestry and fishery } & & 53.5 & 57.6 \\
\hline & $\begin{array}{l}\text { Self-employed } \\
\text { farmer }\end{array}$ & 35.0 & \\
\hline & $\begin{array}{l}\text { Self-employed } \\
\text { fisherman }\end{array}$ & 2.1 & \\
\hline & Day labourer & 16.4 & \\
\hline \multirow[t]{5}{*}{ Non-agricultural } & & 30.2 & 41.3 \\
\hline & Trade & 15.0 & 16.6 \\
\hline & Ferry/taxi worker & 5.5 & 8.5 \\
\hline & Service & 6.5 & 5.9 \\
\hline & Construction worker & 3.2 & 3.2 \\
\hline Households with sanitary latrine facility (\%) & & 25.3 & 20.6 \\
\hline Households with electricity connection (\%) & & 45 & 31.2 \\
\hline Tube-well as main drinking water source (\%) & & 98.8 & 95.8 \\
\hline Main sources of household energy (\%) & $\begin{array}{l}\text { Twigs/leaves/ } \\
\text { straw/dung }\end{array}$ & 82.8 & $\mathrm{~N} / \mathrm{A}$ \\
\hline $\begin{array}{l}\text { Average number of family members } \\
\text { (min-max) }\end{array}$ & & $5.6(1-26)$ & 5.2 \\
\hline $\begin{array}{l}\text { Average household income (USD/year) } \\
\text { (standard deviation) }\end{array}$ & & 1,291 (1424) & 1,044 \\
\hline Median household income (USD/year) & & 846 & - \\
\hline $\begin{array}{l}\text { Average per capita income (USD/month) } \\
\text { (standard deviation) }\end{array}$ & & $14(20.3)$ & 14 \\
\hline Median per capita income (USD/month) & & 12.4 & - \\
\hline Households owning agricultural land (\%) & & 58.4 & $65.6^{a}$ \\
\hline
\end{tabular}

Note:

a. National statistics considers farmers owning less than 0.5 hectare firm land as 'landless'.

Source: Bangladesh Bureau of Statistics (2005). 
Table 2 Cross-tabulation results between insurance familiarity and the decision to participate in an insurance scheme

\begin{tabular}{|l|l|l|l|}
\hline \multirow{2}{*}{} & & \multicolumn{2}{|c|}{ Willing to buy insurance (\%) } \\
\cline { 3 - 4 } Familiarity with insurance & No & Yes \\
\hline & Not familiar at all & 78 & 22 \\
\hline & Not familiar & 70 & 30 \\
\hline & Somewhat familiar & 40 & 60 \\
\hline Familiar & 30 & 70 \\
\hline & Completely familiar & 25 & 75 \\
\hline
\end{tabular}

between education and insurance familiarity $(\mathrm{r}=0.2 \mathrm{I} 6 ; \mathrm{p}<0.00 \mathrm{I})$, which indicates that respondents with a higher level of education are more familiar with insurance.

The group of respondents refusing to participate in the insurance scheme due to income constraints earned USD 822 per year whereas the average annual income of the group of respondents who refused to take part for other reasons was USD I,60I. The difference in mean yearly income between the two groups of respondents is statistically significant (Mann-Whitney $Z=-\mathrm{IO} .20$; $\mathrm{p}<0.00 \mathrm{I}$ ). The most unpopular feature of the proposed insurance scheme is that the insured will not receive a monetary return in the event of no disaster occurring. This was mentioned by 65 per cent of respondents, who specified 'dislike of terms and conditions' as their main reason for non-participation. The group of respondents that refused to participate due to income constraints was also less familiar with the concept of insurance than others (Chi square $=8 \mathrm{I}, \mathrm{p}<0.00 \mathrm{I}$ ), whereas respondents who did not want to participate in the insurance programme because they disliked the terms and conditions were more familiar with insurance than other respondents (Chi square $=$ I, $\mathrm{p}<0 . \mathrm{OoI}$ ). No significant difference was observed between insurance familiarity and respondents' lack of ability to assess the usefulness of insurance and respondents' mistrust of insurance providers.

Respondents who agreed in principle to buy micro flood insurance were given the opportunity to choose from different types of products. One-half of the respondents wanted to insure their crop yield against flood risks while slightly more than onequarter wanted to buy insurance for house property damage, followed by another 20 per cent who preferred unemployment insurance. Around two-thirds of the respondents who wanted to participate in the flood insurance programme preferred central government as the provider of the scheme. More than 80 per cent of the sample believed that the central government is responsible for the management of flood risks.

\section{Public willingness to pay for micro flood insurance}

A double-bounded dichotomous choice format was used to elicit respondents' willingness to pay for flood insurance. Respondents were asked two questions: do you 
accept a start bid of $c_{i}$ ?; and do you accept a follow-up bid of $b_{i}$ ? Based on their answers, four possible intervals for WTP were constructed:

- $\mathrm{WTP}=\mathrm{I}$ : rejecting both the start bid $\left(c_{i}\right)$ and the follow-up bid $\left(b_{i}\right)$;

- $\mathrm{WTP}=2$ : rejecting the start bid $\left(c_{i}\right)$ but accepting the follow-up bid $\left(b_{i}\right)$;

- $\mathrm{WTP}=3$ : accepting the start bid $\left(c_{i}\right)$ but rejecting the follow-up bid $\left(d_{i}\right)$;

- $\mathrm{WTP}=4$ : accepting both the start bid $\left(c_{i}\right)$ and the follow-up bid $\left(d_{i}\right)$.

Using the statistical assumptions underlying interval regression (Hanemann, Loomis and Kanninen, I99I; Alberini, I995), three interval regression models were estimated for the three most preferred insurance schemes. Mean WTP values were derived from a simple model where the intervals are regressed on the starting bid (Hanemann and Kanninen, 1999), following the conventional procedure for binary WTP response data (Hanemann, I984). The results are presented in Table 3. Floodplain residents' WTP is highest for crop insurance, followed by property insurance and then unemployment insurance. Mean WTP for crop insurance is USD o.6o per household per week, USD 0.45 per week for house insurance and USD 0.43 per week for unemployment insurance. Although the difference between mean WTP for property and unemployment insurance is small, it is statistically significant.

The estimated mean WTP amounts were treated as the expected premium to be received by the insurer. Given that the insurer receives a premium flow until the disaster event strikes at some point in the future, future values of the expected premium income needed to be calculated in order to make a comparison with one-off damage compensation payable to the insured. The future values of the average premium were calculated using the following formula for a future value of an annuity:

$P_{i}=W T P_{i} \star \frac{(\mathrm{I}+r)^{n}-\mathrm{I}}{r}$

Where:

$\mathrm{P}_{\mathrm{i}}=$ future value of the revenues from insurance premiums (per insurance contract);

$\mathrm{r}=$ nominal interest rate;

$\mathrm{n}=$ number of years;

$\mathrm{WTP}_{\mathrm{i}}=$ average willingness to pay per insurance scheme per year; and i refers to a specific insurance scheme.

Table 3 Mean WTP of the sample population for three insurance schemes ${ }^{2}$

\begin{tabular}{|l|l|l|l|}
\hline \multirow{2}{*}{} & \multicolumn{3}{|c|}{ Insurance scheme } \\
\cline { 2 - 4 } & House property & Crop & Unemployment \\
\hline Mean WTP (USD/week) & 0.46 & 0.60 & 0.43 \\
\hline $95 \%$ confidence interval (Cl) & $0.43-0.47$ & $0.57-0.62$ & $0.41-0.46$ \\
\hline
\end{tabular}


Table 4 Future value of expected insurance premium for different insurance schemes (in USD)

\begin{tabular}{|c|c|c|c|c|c|c|c|}
\hline \multirow{2}{*}{\multicolumn{2}{|c|}{$\begin{array}{l}\text { Flood probability } \\
\text { Interest rate }\end{array}$}} & \multicolumn{2}{|c|}{ High } & \multicolumn{2}{|c|}{ Medium } & \multicolumn{2}{|c|}{ Low } \\
\hline & & $5 \%$ & $10 \%$ & $5 \%$ & $10 \%$ & $5 \%$ & $10 \%$ \\
\hline \multirow{3}{*}{$\begin{array}{l}\text { Insurance } \\
\text { product }\end{array}$} & Crop & 173.3 & 191.5 & 299.5 & 358.7 & 394.5 & 499.9 \\
\hline & House property & 132.3 & 146.1 & 228.6 & 273.7 & 301.1 & 381.5 \\
\hline & Unemployment & 127.7 & 141.1 & 220.7 & 264.3 & 290.7 & 368.3 \\
\hline
\end{tabular}

Three different flood probabilities were used to measure the number of years (n): high; medium; and low. These flood probabilities refer to floods occurring once every five years (high), eight years (medium) and ıo years (low), respectively. Two different market interest rates were employed to represent market conditions in Bangladesh: five per cent and Io per cent. Table 4 presents the estimated future values of expected insurance premium revenues. These future values vary positively with estimated WTP and the interest rate and negatively with flood probabilities. A higher value of estimated average WTP and a higher market interest rate result in a higher future value of the expected insurance premium, ceteris paribus. However, a higher flood probability generates a lower value of ' $n$ ' in Equation I and therefore the future value of the expected insurance premium decreases. Consequently, expected future values of the insurance premium are high when a low flood probability is assumed and low when a high flood probability is assumed.

\section{Commercial viability of micro flood insurance}

The condition for a financially viable insurance contract can be written in the following form (Hazell, I992):

$$
\frac{A+I}{P}<\mathrm{I}
$$

Where:

$\mathrm{A}=$ average administration costs per insurance contract;

$\mathrm{I}=$ average indemnities paid; and

$\mathrm{P}=$ average premiums paid.

According to Equation 2, the premium collected on an insurance scheme must exceed the expected value of the average payout (indemnity) in order to ensure the viability of the insurance contract and the administration costs per insurance contract. The term 'indemnity' refers to the amount of financial transfer payable by the insurer to the insured. A proxy for expected indemnity payments for different 
Table 5 Comparison of administration costs for different insurance providers (in USD)

\begin{tabular}{|l|l|l|l|l|}
\hline & $\begin{array}{l}\text { Delta Life } \\
\text { Insurance } \\
\text { Company' }\end{array}$ & $\begin{array}{l}\text { Microinsurance } \\
\text { Mutual Entity } \\
\text { (MIME) Pilot } \\
\text { Project }\end{array}$ & $\begin{array}{l}\text { Sadharan Bima } \\
\text { Corporation }\end{array}$ & $\begin{array}{l}\text { Green Delta } \\
\text { Insurance } \\
\text { Company Limited }\end{array}$ \\
\hline & $\begin{array}{l}\text { A private life } \\
\text { insurance company } \\
\text { offering micro life } \\
\text { insurance }\end{array}$ & $\begin{array}{l}\text { A collective of MFIs/ } \\
\text { NGOs offering life } \\
\text { insurance }\end{array}$ & $\begin{array}{l}\text { The Bangladesh } \\
\text { public general } \\
\text { insurer }\end{array}$ & $\begin{array}{l}\text { An example of a } \\
\text { private general } \\
\text { insurer }\end{array}$ \\
\hline $\begin{array}{l}\text { Administration costs } \\
\text { per client per year }\end{array}$ & $6^{\text {a }}$ & $16^{\text {a }}$ & 14 & 22 \\
\hline
\end{tabular}

Notes:

${ }^{\mathrm{I}}$ Source: McCord and Churchill (2005).

${ }^{2}$ Source: INAFI Bangladesh (2007).

${ }^{3}$ Source: Sadharan Bima Corporation (2005)

${ }^{4}$ Source: Green Delta Insurance Company Limited (2005)

a These costs do not include the cost of reinsurance.

insurance schemes was established using average damage costs incurred by households in the disaster flood year of 2004. Administration costs are the costs to the insurer of managing and operating the insurance business, and include salaries, legal fees, utilities, and depreciation of office space, equipment and supplies. Administration costs also commonly include the cost of reinsurance premiums to the insurer. These costs vary depending on the type of risk, the kind of provider and the size of their client base. Table 5 presents an overview of the range of administration costs incurred by some mainstream insurance providers as well as by MFIs/NGOs. The costs vary from USD 6-22 per client per year. The financial viability of a new micro flood insurance contract was tested using the highest (USD 22) and the lowest (USD 6) administration cost per contract.

Two different micro-insurance organisational models were applied: a 'partneragent' (PA) model and a 'full-service'(FS) model (Cohen and McCord, 2003). The basic difference between them arises from the organisational structure, which produces a substantial difference in the implementation and administration costs. In a FS model, insurers provide all kinds of services, such as risk bearing, design of the insurance product, distribution, premium collection, damage assessment and compensation disbursement. In a PA model, insurance companies and micro-credit providers collaborate to offer the insurance schemes jointly. Generally, insurance companies bear the full risk, while micro-credit providers carry out most of the field-level operational and administration work through their established client network. The administration cost of offering, distributing and maintaining insurance contracts under such a scheme is expected to be reduced to a negligible amount per insurance contract. A case study of micro-insurance and micro-finance institutions in India documents an administration cost of USD I.8 per insurance contract per year under the PA model (Roth et al., 2005). In some cases, the administration cost has been found to be as low as USD 0.5 (ILO, 2006). An administration cost of USD 2 per insurance 
contract is assumed here in order to test the commercial viability of micro-insurance supply under the PA model.

Table 6 presents the commercial viability test results of different insurance schemes under a PA model assuming an administration cost of USD 2. The indemnity-premium

Table 6 Financial viability of three micro-flood insurance contracts under PA model

\begin{tabular}{|l|l|l|l|l|l|l|l|}
\hline & & \multicolumn{2}{c|}{ High } & \multicolumn{3}{c|}{ Medium } & \multicolumn{2}{c|}{ Low } \\
\hline Interest rate & $5 \%$ & $10 \%$ & $5 \%$ & $10 \%$ & $5 \%$ & $10 \%$ \\
\hline & & $(\mathrm{A}+\mathrm{I}) / \mathrm{P}$ & $(\mathrm{A}+\mathrm{I}) / \mathrm{P}$ & $(\mathrm{A}+\mathrm{I}) / \mathrm{P}$ & $(\mathrm{A}+\mathrm{I}) / \mathrm{P}$ & $(\mathrm{A}+\mathrm{I}) / \mathrm{P}$ & $(\mathrm{A}+\mathrm{I}) / \mathrm{P}$ \\
\hline $\begin{array}{l}\text { Insurance } \\
\text { product }\end{array}$ & Crop & 2.24 & 2.03 & 1.32 & 1.12 & 1.02 & 0.82 \\
\hline & House property & 0.97 & 0.88 & 0.60 & 0.51 & 0.47 & 0.39 \\
\hline & Unemployment & 0.77 & 0.71 & 0.48 & 0.42 & 0.39 & 0.32 \\
\hline
\end{tabular}

Note: $A=U_{S D} 2$

Table 7 Financial viability of three micro-flood insurance contracts under FS model

\begin{tabular}{|c|c|c|c|c|c|}
\hline \multicolumn{2}{|c|}{ Flood probability } & \multicolumn{4}{|c|}{ High } \\
\hline \multicolumn{2}{|c|}{ Interest rate } & \multicolumn{2}{|c|}{$5 \%$} & \multicolumn{2}{|c|}{$10 \%$} \\
\hline \multirow{2}{*}{\multicolumn{2}{|c|}{ Administration cost (USD/year) }} & 6 & 22 & 6 & 22 \\
\hline & & $(A+I) / P$ & $(\mathrm{~A}+\mathrm{I}) / \mathrm{P}$ & $(A+I) / P$ & $(A+I) / P$ \\
\hline \multirow{3}{*}{$\begin{array}{l}\text { Insurance } \\
\text { product }\end{array}$} & Crop & 2.37 & 2.88 & 2.16 & 2.67 \\
\hline & House property & 1.14 & 1.80 & 1.05 & 1.72 \\
\hline & Unemployment & 0.95 & 1.64 & 0.88 & 1.57 \\
\hline
\end{tabular}

\section{Flood probability}

Interest rate

Administration cost (USD/year)

\begin{tabular}{|l|l|}
\hline $\begin{array}{l}\text { Insurance } \\
\text { product }\end{array}$ & Crop \\
\hline & House property \\
\hline Unemployment \\
\hline
\end{tabular}

Flood probability

Interest rate

Administration cost (USD/year)

Insurance

product

\begin{tabular}{l|l}
\hline Crop & 1.15 \\
\hline House property & 0.64 \\
\hline Unemployment & 0.56
\end{tabular}

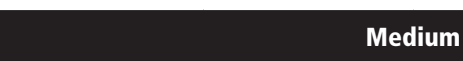

Medium

$5 \%$

$10 \%$

22

$(A+I) / P$

6

22

$(A+l) / P$

1.96

$(\mathrm{A}+\mathrm{I}) / \mathrm{P}$

$(\mathrm{A}+\mathrm{I}) / \mathrm{P}$

1.26

0.81

0.71

1.43

1.24

1.75

0.68

1.35

1.35

0.59

1.28

\section{c}


ratio $[(\mathrm{A}+\mathrm{I}) / \mathrm{P}]$ for crop insurance is below one in a PA model when flood probabilities are low and the market interest rate is high (Io per cent). For all other combinations of flood probabilities and interest rates, the indemnity-premium $[(\mathrm{A}+\mathrm{I}) / \mathrm{P}]$ ratio for crop insurance exceeds one, implying that the expected average premium that households are willing to pay is too low to cover the expected indemnity and administration costs. However, the $[(\mathrm{A}+\mathrm{I}) / \mathrm{P}]$ ratios for the two other insurance schemes, property and unemployment, are less than one for all combinations of flood probability and interest rate. This suggests that in a PA model, property and unemployment insurance are financially viable since the expected revenues exceed the expected indemnity and administration costs.

Changing the organisational design from a PA to a FS model results, as expected, in a substantially different outcome in terms of commercial viability of flood insurance contracts. Table 7 presents the ratio of expected average payouts to expected premium revenues $[(\mathrm{A}+\mathrm{I}) / \mathrm{P}]$ for different insurance contracts assuming a FS model. For crop insurance, the $[(\mathrm{A}+\mathrm{I}) / \mathrm{P}]$ ratio exceeds one for almost all combinations of flood probability, interest rate and administration cost (except in one case where both the flood probability and administration cost are low and the market interest rate is high). If the insurance provider incurs a low supply cost per insurance contract per year, property and unemployment insurance schemes are financially viable in a medium flood probability scenario. In the event of a high administration cost of 22 USD per year per insurance contract, the financial viability prospects of these two insurance schemes become gloomy. Both are financially viable only in a low-tomedium flood probability scenario and when the administration cost is low.

\section{Potential insurance providers' attitudes towards micro flood insurance}

Following the household survey in 2006, in-depth key informant interviews and a workshop were conducted in 2007 with 20 representatives of the government, private insurance companies, and micro-credit providers. The objective was to gain more insight into the opportunities for and threats to micro flood insurance provision in Bangladesh. The key informants selected for the survey were all high-profile decisionmakers. Before the interviews, they were informed about the research aims and the questions. A limited number of preliminary questions were asked to ensure that the key informants came prepared. Each interview lasted at least one hour and was based on a semi-structured questionnaire format.

Besides discussing necessary conditions and criteria related to the potential for setting up a micro flood insurance market in Bangladesh, financial, economic, social and legal motivations and the driving forces of organisational actors in this sector were addressed. Specifically, questions dealt with: governance and regulatory barriers to implementation of a micro flood insurance product; perceptions of the commercial viability of a micro flood insurance product; and views on who should be 
the provider of such a product and prospects for collaboration between private insurance companies and MFIs/NGOs. The key findings are summarised below.

\section{Institutional context}

It was discovered through the interviews that MFIs/NGOs and mainstream insurance providers are governed by different agencies. For MFIs/NGOs, the main governing body is the Microcredit Regulatory Authority (MRA), under the Ministry of Finance. With respect to issuing insurance policies, the governing MRA Act (2006) stipulates that micro-credit institutions have the authority and responsibility to offer different types of insurance services to loan recipients and members of their families. Yet considerable uncertainty remains regarding the implications of the MRA Act for the provision of micro-insurance and - at the time of this study - no specific micro-insurance rules and laws have been established for MFIs/NGOs.

Unlike MFIs/NGOs, mainstream insurance providers operate under the Ministry of Commerce and the Bangladesh Insurance Act (1938), which regulates the insurer's business. The Central Rating Commission, established under this Act, performs the actuarial function for the industry, fixing premium levels for each type of insurance product offered.

\section{Perceptions of commercial viability}

Table 8 summarises key informants' perceptions of the commercial viability of micro flood risk insurance. Most interviewees either did not believe that micro flood insurance would be profitable or were unsure about its commercial prospects. An executive of a private insurance company said that although he did not expect full cost-recovery, the social objectives of such plans are more important than profits. Surprisingly, representatives of both mainstream insurance companies and microfinance organisations stated that they would be interested in and willing to implement

Table 8 Responses to some of the commercial viability questions

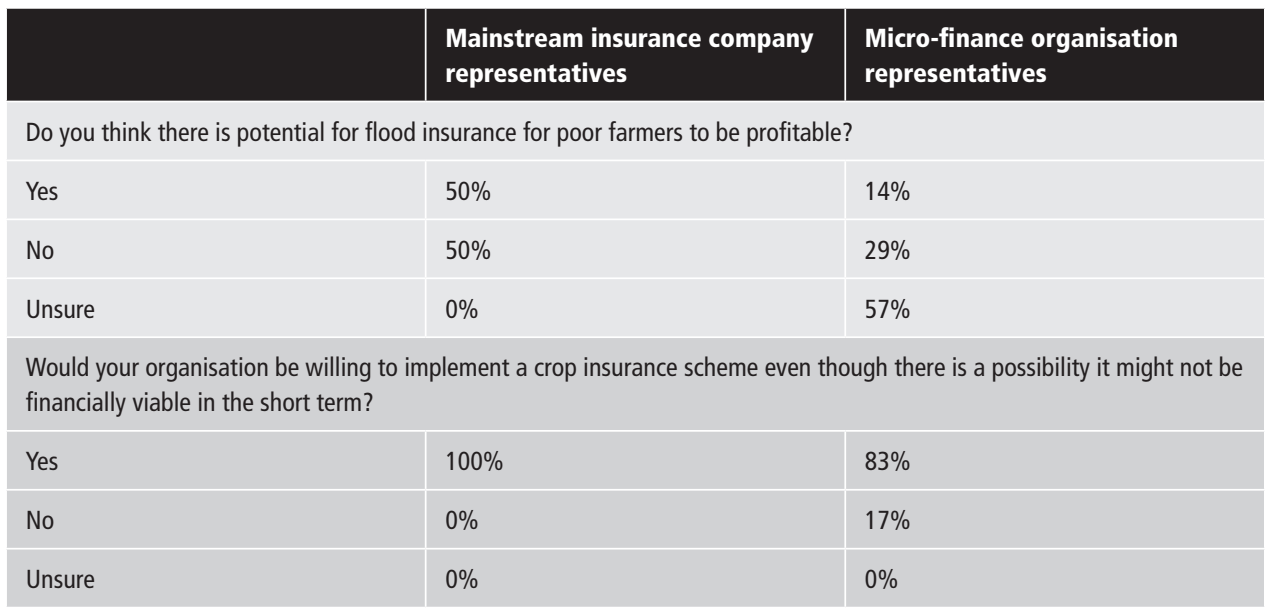


a crop insurance scheme even if there was a possibility that it might not be financially viable in the short term.

Organisations demonstrated different motivations depending on the nature of their operations. Micro-credit providers pointed to social concerns as their prime motivation in considering micro-flood insurance. Several micro-credit providers said that they had been thinking about providing micro-insurance for crops in order to fulfil their social objectives regarding the agricultural and rural development of the country, even though the affordable premium rate for such insurance is too low to ensure financial viability. In contrast, the mainstream private insurance companies pointed to a classic motivation of profit maximisation, which does not come as a surprise considering that such companies are owned by shareholders who scrutinise financial performance as it relates to share price. Although the target clients of insurance providers include both rural and urban poor, mainstream insurance companies give priority to clients with regular income flows, thus precluding individuals with irregular or seasonal income (see also Hasan, 2007).

\section{Prospects for collaboration}

The in-depth interviews revealed that the majority of the key informants from both mainstream insurance companies and micro-finance organisations agreed that neither entity should offer micro-insurance on their own (Table 9). When asked in the interviews about the prospect of collaboration, mainstream insurance company representatives were positive, affirming that they would consider delivering flood insurance in partnership with micro-finance organisations. Respondents from micro-finance

Table 9 Responses to some of the collaborative insurance provision questions

\begin{tabular}{|l|l|l|}
\hline & $\begin{array}{l}\text { Mainstream insurance company } \\
\text { representatives }\end{array}$ & $\begin{array}{l}\text { Micro-finance organisation } \\
\text { representatives }\end{array}$ \\
\hline Should private insurance companies offer micro-insurance on their own? & \\
\hline Yes & $0 \%$ & $33 \%$ \\
\hline No & $100 \%$ & $50 \%$ \\
\hline Unsure & $0 \%$ & $17 \%$ \\
\hline Should microfinance institutions offer micro-insurance on their own? & $33 \%$ & $11 \%$ \\
\hline Yes & $67 \%$ & $89 \%$ \\
\hline No & $0 \%$ & $0 \%$ \\
\hline Unsure & $100 \%$ & $33 \%$ \\
\hline Would you deliver flood insurance in a partnership between private insurance companies and micro-finance organisations?
\end{tabular}


organisations were less positive about potential collaboration, highlighting that mainstream insurers do not care about poor people and that they only seek to maximise profit (Table 9).

The issue of collaboration was further addressed during the workshop at which the administrative heads of leading micro-credit organisations and private insurance companies were invited to participate. Both micro-credit providers and mainstream insurers were identified as having a stake in the outcomes and holding significant power in terms of the structure of a future market, albeit in a different manner. Mainstream insurers have financial power whereas the micro-credit providers have access to a large client base. Combining these two strengths may result in a win-win situation (Mechler et al., 2006; Hasan, 2007). However, disagreement over the type of stake in outcomes (either for financial gain or to achieve poverty-reduction objectives) may imply that the two players are unwilling to cooperate. In that case, provision under the PA model may be impossible. For instance, the invitees at the workshop entered into a heated debate about their respective commitment to poverty eradication and social development in the country. Furthermore, significant disagreement emerged between the two parties over the type of stake in outcomes. Finally, it appeared that the two players were unwilling to cooperate with each other. One of the key informant interviewees summed up this problem as follows: 'collaboration sounds like an interesting idea, however insurance companies are mostly profit-seeking, hence goals are different and the plan, therefore, would suffer under partnership'.

\section{Conclusions and policy implications}

In the context of a growing body of economic literature on the appropriate institutional framework for risk management and insurance provision, this study aimed to test the practicality of insuring poor livelihoods and property damage risks resulting from catastrophic events in developing countries. The results can be summarised as two key findings. First, the research reinforces the scepticism envisaged by Shiller (2003) about potential low effective demand for new insurance products. Only onehalf of the sample respondents agreed to participate in the hypothetical flood insurance programme. Shiller (2003) rightly contends that most people do not appreciate the possibilities inherent in new technologies and, therefore, the process of initiation of such innovations is difficult. It appears from the study results that the introduction of a financial instrument like insurance could be even harder in a developing country where potential buyers are characterised by large-scale illiteracy and widespread poverty.

Second, the research identified some important supply-side obstacles associated with private provision of insurance overlooked by Shiller (2003) and many of his critics. The quantitative analysis demonstrates that a PA model as a specific organisational structure may help to reduce substantially the administration cost of insurance supply and thus some insurance contracts may turn out to be financially viable with respect to their cost-recovery levels. However, in the qualitative part of the analysis, the 
study identified structural problems hindering potential collaboration under a PA model. The key players in the micro-insurance market in Bangladesh vary in terms of their motivations, degree of power and type of stakes they pursue in such a market. These differences make collaboration under such an organisational framework less likely and a potential collaborative agreement unstable. This implies that the political economic context of the financial market in a country plays an important part in determining the prospects of risk-sharing instruments.

Both the quantitative empirical results and the main outcome of the in-depth interviews indicate that the outlook for a micro flood insurance market in Bangladesh is not very positive. One of the key challenges facing policymakers in this regard is, as expected, financial viability. Especially for the most preferred insurance product, crop insurance, a financially viable market can exist only under a PA organisational framework that minimises administration costs. Given the importance of profits among private insurance companies and the gap between the expected premium and the indemnity amount, it seems unlikely that private micro flood insurance can be introduced in Bangladesh at present. However, the empirical investigation only touched on the important issue of risk and transaction cost-sharing in determining the financial viability of a flood insurance market. Institutional and financial motivations and the driving forces of the two main players in the micro flood insurance market have to be reconciled for such a mode of provision to become a reality.

An important question remains as to whether such an insurance programme stands more chance of survival and whether it could become more viable if it was implemented through a public-private partnership. Brown and Churchill (2000) suggest that when determining the appropriate institutional-organisational model, one should not only look at the availability of partners, but also at available human resources and information capabilities, motivations, and the goals underlying plans. In addition, it is important to consider in the organisational models access to clients, access to reinsurance, and, last but not least, access to subsidies and donors. An examination of several annual reports of mainstream insurance companies and micro-credit providers that are currently offering some kind of micro-insurance products revealed that the latter receive a large amount in donations in the form of direct financial transfers. Such transfers affect the affordability of insurance schemes as they can be used to 'top up' premiums.

Given that micro-credit providers expressed interest in offering an affordable insurance scheme and the large inflow of foreign donations in this sector, they may be able to play a key role in developing a micro flood insurance market. Microcredit providers, furthermore, have a competitive advantage in that they have more access to the client base, have better infrastructural facilities across even the most remote parts of Bangladesh, enjoy a greater degree of trust and credibility among clients, and have pre-existing information on client portfolios and risk history. This study also found indications that potential insurance clients prefer public provision of micro flood insurance, possibly because they consider flood risk protection a government responsibility or have a higher degree of trust in the public sector than 
the private sector. However, one should not underestimate the importance of sound actuarial analysis in providing a viable insurance scheme in the long term. This expertise is only available in private insurance companies. A government-directed and -facilitated process to settle and overcome the differences observed in this study between the non-profit micro-credit providers and profit-oriented private insurance companies is needed, building on the particular competences that each party can lend to the development of a viable micro flood insurance market through a publicprivate partnership.

\section{Acknowledgements}

The work presented in this paper was supported by the Poverty Reduction and Environmental Management (PREM) programme in Bangladesh, funded by the Dutch Ministry of Foreign Affairs. The authors gratefully acknowledge the cooperation of the following organisations at various stages of this research: the Bangladesh Water Development Board, the Climate Change Cell at the Department of Environment, the Flood Forecasting and Warning Center, Bangladesh, the Water Resource Planning Organization and the Geographic Information System cell in the Department of Local Government Engineering. We would also like to extend thanks to the team of interviewers in Bangladesh who collected the data as part of this research project.

\section{Correspondence}

Sonia Akter, Crawford School of Economics and Government, Crawford Building, Lennox Crossing, Building \# I32, Australian National University, Canberra ACT 0200, Australia. E-mail: sonia.akter@anu.edu.au

\section{Endnotes}

Sonia Akter is a Research Fellow at the Crawford School of Economics and Government, Australian National University, Australia; Roy Brouwer is Professor in the Department of Environmental Economics, Institute for Environmental Studies, VU University, Amsterdam, Netherlands; Pieter J.H. van Beukering is Associate Professor at the Institute for Environmental Studies, VU University, Amsterdam, Netherlands; Laura French is a postgraduate student at the School of Oriental and African Studies, University of London, United Kingdom; Efrath Silver is a Research Fellow at EcoPeace/Friends of the Earth Middle East, Tel Aviv, Israel; Saria Choudhury is Research and Teaching Assistant at the Department of Economics, BRAC University, Dhaka, Bangladesh; and Syeda Salina Aziz is Research Associate at the Institute of Governance Studies, BRAC University, Dhaka, Bangladesh.

2 The exchange rate used here is 63 Taka per USD.

3 Through interviews and study of annual reports, it was found that no MFIs/NGOs or private insurance companies currently hold reinsurance for their existing micro-insurance plans. 


\section{References}

Alberini, A. (1995) 'Efficiency vs. bias of willingness to pay estimates: bivariate and interval-data models'. Journal of Environmental Economics and Management. 29(2). pp. I69-180.

Bangladesh Bureau of Statistics (2005) 'Key findings of HIES 2005'. http://www.bbs.gov.bd/data index/hies_2005.pdf (accessed on 2I September 2010).

Bouwer, L.M. and P. Vellinga (2002) 'Changing climate and increasing costs - implications for liability and insurance'. In M. Beniston (ed.) Climatic Change: Implications for the Hydrological Cycle and for Water Management. Advances in Global Change Research, Volume Io. Springer, Dordrecht and Boston, MA. pp. 429-444.

Brouwer, R., S. Akter, L. Brander and E. Haque (2007) 'Socio-economic vulnerability and adaptation to environmental risk: a case study of climate change and flooding in Bangladesh'. Risk Analysis. $27(2)$. pp. 313-326.

Brouwer, R., S. Akter, L. Brander and E. Haque (2009) 'Economic valuation of flood risk exposure and control in a severely flood prone developing country'. Environment and Development Economics. I4(3). pp. 397-4I7.

Brouwer, R. and S. Akter (20I0) 'Informing micro insurance contract design to mitigate climate change catastrophe risks using choice experiments'. Environmental Hazards. 9(I). pp. 74-88.

Brown, W. and C. Churchill (2000) Insurance Provision in Low-income Communities. Part II. Initial Lessons from Microinsurance Experiments for the Poor. Micro-enterprise Best Practices. Development Alternatives Inc., Bethesda, MD.

Botzen, W.J.W. and J.C.J.M. van den Bergh (2008) 'Insurance against climate change and flooding in the Netherlands: present, future, and comparison with other countries'. Risk Analysis. 28 (2). pp. 4I3-426.

Cohen, M. and M. McCord (2003) Financial Risk Management Tools for the Poor. MicroInsurance Centre Briefing Note 6. http://www.microfinanceopportunities.org/docs/Financial_Risk_Management_ Tools_for_the_Poor_\%2oCohenMcCorddec2003.pdf (accessed on 2I September 20I0).

Dowd, K. (2003) 'Review of "the new financial order": risk in the 2Ist century'. Cato Journal. 23(2). pp. $335-340$

Duncan, J., and R.J. Myers (2000) 'Crop insurance under catastrophic risk'. American Journal of Agricultural Economics. $82(4)$. pp. 842-855.

Dworkin, R. (2000) Sovereign Virtue: The Theory and Practice of Equality. Harvard University Press, Cambridge, MA.

Farrelly, C. (2007) 'Justice in ideal theory: a refutation'. Political Studies. 55(4). pp. 844-864.

Gine, X., R. Townsend and J. Vickery (2008) 'Patterns of rainfall insurance participations in rural India'. The World Bank Economic Review. 22 (3). pp. 539-566.

Green Delta Insurance Company Limited (2005) Annual Report 2005. Green Delta Insurance Company Limited, Dhaka.

Hanemann, W.M. (1984) 'Welfare evaluations in contingent valuation experiments with discrete responses'. American Journal of Agricultural Economics. 66(3). pp. 332-34I.

Hanemann, W.M., J.B. Loomis and B. Kanninen (I99I) 'Statistical efficiency of double bounded dichotomous choice contingent valuation'. American Journal of Agricultural Economics. 73(4). pp. I255-I263.

Hanemann, W.M. and B. Kanninen (I999) 'The statistical analysis of discrete-response CV data.' In I.J. Bateman and K. G. Willis (eds.) Valuing Environmental Preferences: Theory and Practice of the Contingent Valuation Method in the US, EU, and Developing Countries. Oxford University Press, New York, NY. pp. 302-44I.

Hasan, R.A. (2007) Reducing Vulnerability of the Poor through Social Security Products: a Market Survey on Microinsurance in Bangladesh. International Network of Alternative Financial Institutions, Oxfam Novib, Dhaka. 
Hazell, P.B.R. (1992) 'The appropriate role of agricultural insurance in developing countries'. Journal of International Development. 4(6). pp. 567-58I.

Hoff, H., L. Bouwer, W. Berz, W. Kron and T. Loster (2003) Risk Management in Water and Climate - the Role of Insurance and Other Financial Services. International Dialogue on Water and Climate, Delft, and Munich Reinsurance Company, Munich.

INAFI (International Network of Alternative Financial Institutions) Bangladesh (2007). Business Plan for Microinsurance Mutual Entity (MIME) Pilot Project. INAFI Bangladesh, Dhaka.

IPCC (Intergovernmental Panel on Climate Change) (2007) Climate Change 2007: Impacts, Adaptation, and Vulnerability. IPCC, Geneva.

Kalavakonda V. and O. Mahul (2005) Crop Insurance in Karnataka. World Bank Policy Research Working Paper 3654. World Bank, Washington, DC.

McCord, M.J. and C. Churchill (2005) Delta Life, Bangladesh CGAP Working Group on Microinsurance, Good and Bad Practices. Case Study No. 7. The Microfinance Gateway, Washington, DC.

Mechler, R., J. Linnerooth-Bayer and D. Peppiatt (2006) Disaster Insurance for the Poor? A Review of Microinsurance for Natural Disaster Risks in Developing Countries. ProVention Consortium, Geneva.

Miah, N.H. (1992) Possibility of Introducing Crop Loan Insurance Programme with Public and Private Sector Participation'. Discussion Paper. Bangladesh Insurance Association, Dhaka.

Mills, E. (2004) Insurance as an Adaptation Strategy for Extreme Weather Events in Developing Countries and Economies in Transition: New Opportunities for Public-Private Partnerships. Report No. 52220. Lawrence Berkeley National Laboratory, Berkeley, CA.

Ministry of Environment and Forest Government of the People's Republic of Bangladesh (2005) National Adaptation Programme of Action. Final Report. United Nations Framework Convention on Climate Change, Bonn.

Mitchell, R.C. and R.T. Carson (1989) Using Surveys to Value Public Goods: The Contingent Valuation Method. Resources for the Future, Washington, DC.

ProVention Consortium/IIASA (International Institute for Applied Systems Analysis) (2005) Invest to Prevent Disaster Risk. The Potential Benefits and Limitations of Microinsurance as a Risk Transfer Mechanism for Developing Countries. Viewpoint for International Day for Disaster Reduction, I2 October. United Nations International Strategy for Disaster Reduction Secretariat (UNISDR), Geneva.

Rahman, P. (2007) Agriculture Insurance - Bangladesh Perspective. Green Delta Insurance Company Limited, Dhaka. Unpublished.

Raju, S.S. and R. Chand (2008) Agricultural Insurance in India Problems and Prospects. NCAP Working Paper No. 8. National Centre for Agricultural Economics and Policy Research (Indian Council of Agricultural Research), New Delhi.

Rose, S.A. (2004) 'Review of the new financial order by Shiller'. Journal of Economic Literature. 42 (4). pp. I098-IIOI.

Roth, J., C. Churchill, G. Ramm and Namerta (2005) Microinsurance and Microfinance Institutions Evidence from India, CGAP Working Group on Microinsurance, Good and Bad Practices. Case Study No. I5. International Labour Organization, Geneva.

Sadharan Bima Corporation (2005) Annual Report 2005. Sadharan Bima Corporation, Dhaka.

Shiller, R.J. (2003) The New Financial Order: Risk in the 21st Century. Princeton University Press, Princeton, NJ. 